\title{
The Impact of Macroeconomic Factors on FDI Attractiveness: Romania, Slovakia and Greece in Comparison
}

\author{
Kalliopi Kasapi, Andriana Lampou, George Economakis, \\ George Androulakis, and Ioannis Zisimopoulos
}

\section{Introduction}

The aim of this contribution is to investigate the key macroeconomic factors that may affect inward FDI in rather small European economies, such as Romania, Slovakia and Greece, which are all at a different level in their process of European integration. Romania and Slovakia are both economies in transition. Romania is a member of the EU but still not a member of the EMU while Slovakia and Greece are both members of the EU and the EMU.

The main macroeconomic factors evaluated are inward FDI, GDP growth, real unit labor costs (ULC), trade balance, exchange rate, sectoral distribution of exports, and economic complexity.

\section{Theoretical Frameword}

FDI can contribute to an economy's growth through being a source of capital formation and through technology transfer, "externalities" or "spillover effects" (Fan and Dickie 2000, p. 314) and GDP growth deriving from the improvement of the host country's trade balance. This contribution focuses on the latter.

\footnotetext{
K. Kasapi $(\bowtie) \cdot$ A. Lampou $(\bowtie) \cdot$ G. Economakis $(\bowtie) \cdot$ G. Androulakis $(\bowtie) \cdot$

I. Zisimopoulos $(\square)$

University of Patras, Patras, Greece

e-mail: economak@upatras.gr; gandroul@upatras.gr 


\subsection{Main FDI Categories}

The following FDI categories can be distinguished according to their effect on the host country's trade balance.

1. FDI for producing goods for the domestic market that could operate either as a substitute for investors' exports or equivalently for the host country's imports ("market-seeking" FDI) (Iammarino and Pitelis 1999, pp. 4-5; Lim 2001, pp. 11-12).

This FDI category includes "market-oriented theories for FDI" (Busch 1992, pp. 201-208). It is argued that market-seeking FDI could replace the imports of products of the host country (Iammarino and Pitelis 1999, p. 4; Busch 1992, p. 204; Lim 2001, p. 11) and therefore, ceteris paribus, an improvement of its trade balance is expected. The main incentives of this FDI category are related to the reduction of costs necessary for supplying the domestic market (and thus to increased capital profitability); these costs come from the imposition of duties on the imported goods (Lim 2001, p. 11), national currency devaluation (Busch 1992, pp. 204-205), or from transport costs (Busch 1992, p. 202; Lim 2001, p. 11). Economic growth, as it is expressed by GDP growth, is an indicator of an augmenting domestic market and may explain the increase of marketseeking FDI.

2. FDI for producing goods for the global market (Giannitsis 1983, pp. 300-355; Milios and Ioakeimoglou 1990, pp. 158-159; Iammarino and Pitelis 1999, pp. 4-5; Lim 2001, pp. 11-12; Economakis et al. 2005).

This FDI category includes the "cost-oriented theories for FDI" or the "theories of mobility/allocation of production for cost reasons" (Busch 1992, pp. 201-208). FDI is connected to the "decentralization of stages of production" (Iammarino and Pitelis 1999, p. 4) and the "relocation of the chain in a low-cost location" (Lim 2001, p. 11). The main incentives of this FDI category are related to the reduction of production costs for supplying the global market, such as the reduction of labor costs and the costs of raw materials as well as the opportunity to access to certain "externalities" (e.g. "cluster of FDI in one location", which is referred as "agglomeration") (Lim 2001, p. 11). The transport costs and the proximity of the markets to which the investor's products are exported should be taken under consideration (Economakis et al. 2005) while the market size of the host country does not seem to play a key role (Lim 2001, pp. 11-12). This FDI category is, ceteris paribus, positively related to the improvement of the host country's trade balance since FDI tends to increase the host country exports.

It must be noted that FDI of the first category could be interconnected with the FDI of the second category as inputs that reinforce the export-oriented FDI.

However, the increasing FDI of both categories may cause an increase of imports due to the export orientation of foreign industries in the supply of intermediate inputs, especially if the sectors in which foreign investment activity is concentrated are weakly interconnected with other sectors of the host economy (Giannitsis 1983, p. 353). 
3. FDI that facilitates the foreign investor's imports (Iammarino and Pitelis 1999, pp. 4-5; Lankes and Venables 1996), which is negatively related to the host country's trade balance, or FDI for establishing commercial distribution networks through which domestic products are exported to global markets, which could improve the host country's trade balance.

4. FDI for domestic production in non-tradable goods and services sectors ${ }^{1}$ that are directed to the host country's domestic market (such as the first FDI category). This FDI category does not replace the investor country's exports and it is not directly related to the host country's trade balance.

5. FDI directed to financial intermediation which is not connected directly to the production or to the commercial sphere (Tsantilas 2009, p. 19) but aims to exploit investment opportunities within the host country and has an ambiguous impact on the host country's trade balance.

The following analysis is restricted to the investigation of FDI of the first and second categories.

\subsection{FDI and Economic Complexity}

Economic complexity, which depicts the level of economic development, may influence inward FDI. Economic complexity is "a measure of the knowledge in a society as expressed in the products it makes and is calculated based on the diversity of a country's goods exports and their ubiquity, or the number of the countries able to produce them" and it is measured by the Economic Complexity Index (ECI) (Atlas of Economic Complexity)". "Complex economies are those that can weave vast quantities of relevant knowledge together, across large networks of people, to generate a diverse mix of knowledge-intensive products. Simpler economies, in contrast, have a narrow base of productive knowledge and produce fewer and simpler products which require smaller webs of interaction" (Hausmann et al. 2011). Since "webs of interaction" is another name for "externalities", "complex economies" are, ceteris paribus, attractive destinations for FDI, especially those directed to high-tech sectors.

\section{FDI in the Context of European Integration}

The incentives of the first two FDI categories will be assessed considering their possible positive effect on the host country's trade balance. The imposition of duties, the devaluation of national currency, the geographic position of the country, and

\footnotetext{
${ }^{1}$ Electricity, construction, transportation and storage services, telecommunication services, wholesale and retail trade, and other services (Gibson 2010, p. 340).
} 
GDP growth will be evaluated according to their effect on FDI of the first category. Moreover, the ULC and the proximity of markets will be evaluated according to their effect on FDI of the second category.

\subsection{The Case of Romania}

\subsubsection{Market-Seeking FDI: Tariffs, GDP, and National Currency}

As it can be seen from Fig. 1 Romania's FDI stock as a percentage of the world total (FDI-w.t.percentage) had an upward trend until 2008. In 2008, 1 year after Romania's accession to the EU, the country attracted a record amount of FDI. Between the years 2000 and 2008, large multinational companies invested in the country, while between 2003 and 2005, Romania received the highest rates of FDI inflows in Eastern Europe (Andrei 2014). However, after 2008, the relative position of the country as a receiver of FDI deteriorated significantly, since FDI stock in Romania diminished from $0.42 \%$ of the world total in 2008 to $0.27 \%$ in 2016 (UNCTAD).

Romania embarked on its journey towards EU membership in 1993 with the signing of the Europe Agreement, whose purpose was to prepare the country for accession to the EU (1995-2005). The Agreement was asymmetric in nature, with the EU willing to eliminate its trade barriers for Romanian exports over the first half of the period and Romania doing the same for EU exports over the second half. This concession given by the EU together with the preferential fiscal regime for Romanian exporters brought results in terms of a solid increase in Romanian exports

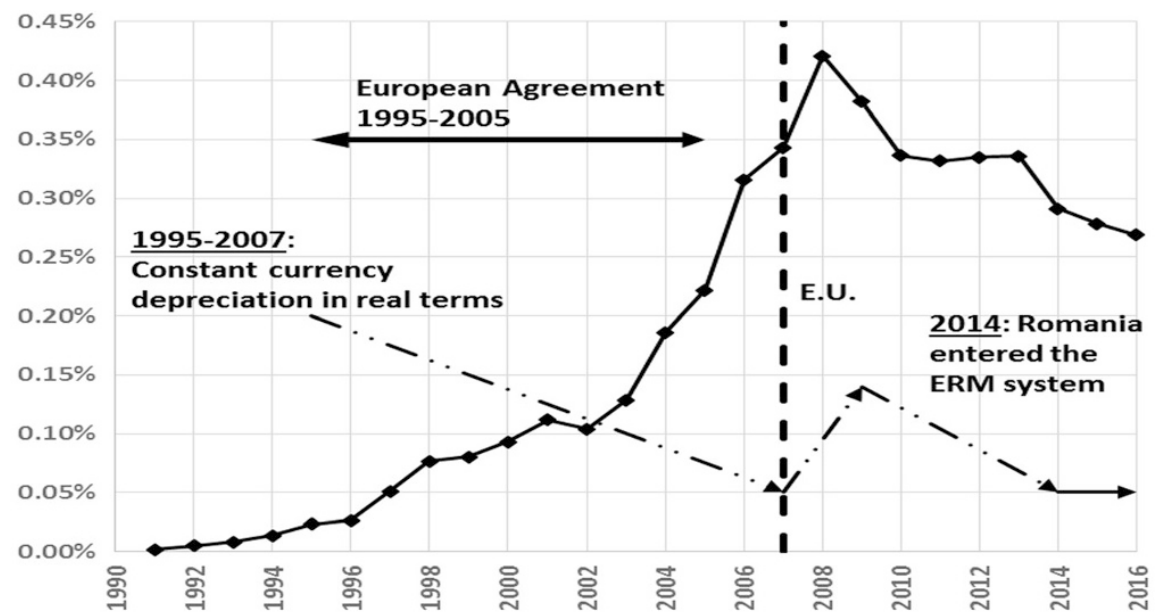

Fig. 1 FDI stock of Romania (\% of total world), 1991-2016. Source: UNCTAD \& IMF 
(Marinescu and Szeles 2010). After 1995 the phasing out of tariffs began, a course necessary before the country's accession to the EU. Taking into account the high dependence on Romania's FDI coming from the EU members (NBR), a negative effect on attracting FDI of the first category would be expected. However, FDI was not affected negatively by the tariffs phasing out, which continued to increase during the same period. The same does not apply after the country accession to the EU in 2007.

Another incentive for attracting market-seeking FDI is the country's national currency exchange rate. Between the years 1995 and 2008, FDI in Romania had an upward trend and the currency showed a trend of devaluation in real terms (IMF). Part of the increase of FDI could be explained by the devaluation of the Romanian national currency, i.e. FDI in order to circumvent the exchange rate protection. Therefore, although the incentive to circumvent tariff protectionism for attracting FDI has faded out, the incentive to circumvent the exchange rate protection remains for foreign firms.

A rising GDP could be another possible incentive for attracting FDI. Romania's FDI-w.t.percentage and GDP increased almost simultaneously between the years 1994 and 2008, decreased between 2008 and 2009, and after 2009 they disconnected (AMECO). The two variables have a weak positive relationship $(\rho=0.44)$ between the years 1994 and 2016. Romania's FDI and GDP common rising trend until 2008 probably indicates that the market size is related to the increased FDI. However, after 2009, FDI and GDP disconnect, indicating that market size changes don't affect market-seeking FDI.

The geographical distance between the investor's country and the host country and the transportation costs don't seem to play a significant role in attracting marketseeking FDI since Romania's main investors (NBR) and trade partners are nearby countries of the EU (UNCTAD).

\subsubsection{Export-Oriented FDI: Wage-Productivity Relationship and Geographic Proximity}

Romania's ULC constantly decreased between the years 1990 and 2016 (AMECO). This downward trend could explain, to some extent, the increase of FDI inflows over the same period. However, the same factor does not seem to be strong enough to reverse the decline of FDI in the Romanian economy after 2008. The strong negative correlation of FDI-w.t.percentage and ULC between the years 1990 and 2016 $(\rho=-0.76)$ means that the level of ULC may influence the level of export-oriented FDI attracted by Romania.

The geographic proximity of Romania with the other EU counties, which are its main investors, could also be an incentive for export-oriented FDI. 


\subsubsection{FDI and Trade Balance of Romania}

Figure 2 depicts Romania's FDI-w.t.percentage as well as the rate of coverage of imports (M) by exports (X) of goods (exports/imports).

Between the years 1994 and 2008, Romanian FDI constantly increased while the trade balance deteriorated. On the contrary, after 2009, the Romanian trade balance improved despite the downturn of FDI, which indicates that FDI is strongly negatively related to external trade. FDI-w.t.percentage and X/M have a strong negative relationship between the years 1994 and $2016(\rho=-0.96)$, indicating a disconnection between FDI and external trade.

In an attempt for further analysis, exports and FDI-w.t.percentage have a strong positive correlation $(\rho=0.77)$ between the years 1994 and 2016, which could indicate the presence of export-oriented FDI. Imports and FDI-w.t.percentage have a strong positive correlation $(\rho=0.87)$ for the same period. Romanian FDI inflows don't seem to have significantly replaced imports. Nevertheless, the increase of imports could be partly explained as a result of FDI inflows in Romania since FDI can create import-demands necessary for the production process. The trade balance improved after 2009, which could be related to the current account crisis of the Romanian economy and the implementation of restrictive policy measures that led to an import decrease and an improved trade balance (Economakis et al. 2016).

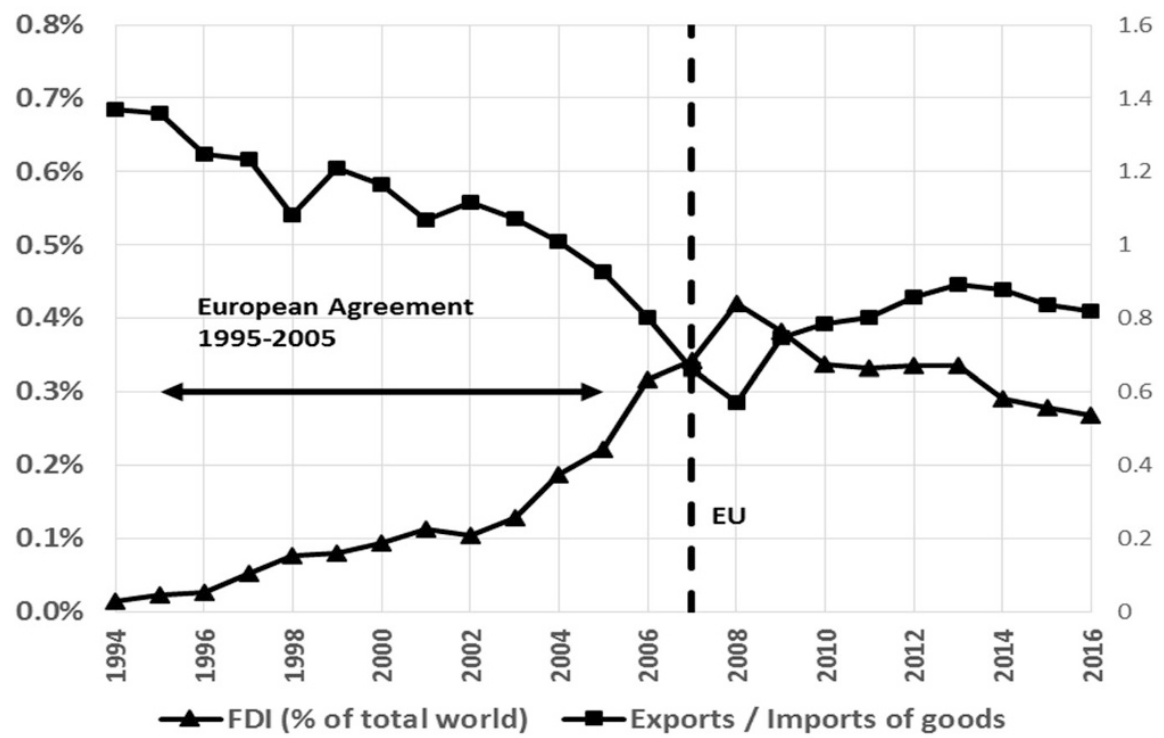

Fig. 2 FDI stock (\% total world) and exports/imports of goods of Romania (1994-2016). Source: UNCTAD \& AMECO 
Summarizing, the received FDI of the first and second category were not strong enough to significantly affect the trade balance, throughout the period examined, despite the presence of FDI of the second category. FDI in Romania is mostly attracted by non-tradable sectors or sectors that are not connected to external trade. In 2004 the service sector was absorbing $46 \%$ and the industry sector $54 \%$ of the total FDI received by Romania while in 2016 the service sector absorbed $55 \%$ and the industry sector 45\% (NBR, Annual reports 2004-2016). This confirms that an important part of FDI is attracted by non-tradable sectors (trade, telecommunications) or sectors with an unclear impact on trade balance (financial intermediation, real estate). In 2007 financial intermediation absorbed $23 \%$ and trade $14 \%$ of the total FDI received by the country (NBR, Annual reports 2004-2016).

\subsubsection{Romania's FDI Positions by Industry \& Exports and Imports Structure}

Figure 3 depicts the distribution of Romanian FDI by industry between 2004 and 2016 (NBR, Annual reports 2004-2016). By comparing the distribution of Romanian FDI by industry with the distribution of the country's imports and exports some conclusions can be derived about the FDI category received. The composition of Romanian exports has changed over time. Textiles and clothing represented the major export products (about one-fourth of all exports) but they lost their top spot after 2003. More specifically, the exports of the industry decreased from $27 \%$ of

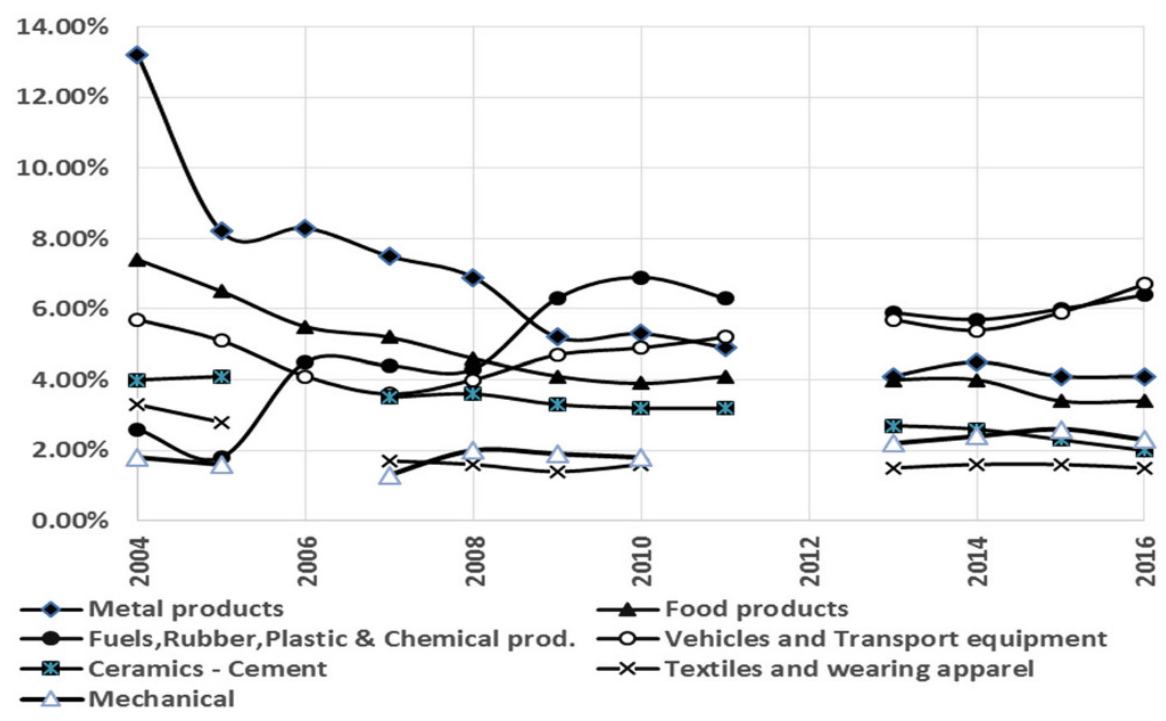

Fig. 3 FDI distribution by industry (2004-2016), (\% of total FDI positions of Romania). Source: NBR 
the total Romanian exports in 2007 to 7\% in 2016, while the industry's imports decreased to $7 \%$ of the total imports in 2016 from 19\% in 1997 (UNCTAD). The textile industry has also experienced a decline in FDI, which suggests that the industry is generally unattractive; it also indicates disinvestment. Since there is a major decline in the exports, imports, and FDI of textile products, there is evidence that the FDI attracted could be of the second category.

There is also a significant increase in the Romanian export of vehicles and transport equipment, which seems to be directly related to the FDI attracted in this sector, especially after Renault acquired the Romanian automaker Dacia in 1999 and Ford Motor Co. made major investments in Romania in 2008 (Marinescu and Szeles 2010). Moreover, the industry's export increased from 5\% of the total exports in 1999 to $17 \%$ in 2016 (UNCTAD). FDI also increased, reaching $6.7 \%$ of the total FDI in 2016 (NBR, Annual reports 2004-2016), indicating that the FDI attracted is mainly of the second category.

There is also a major development of exports of mechanical products, mainly triggered by automotive parts and components. Romania's strong presence in the automotive industry is illustrated by the fact that "there is virtually no car producer in Europe that does not use spare parts produced in Romania, in other words, the assembly lines in Europe are supported by exports of Romania" (Dobreanu 2014). The exports of mechanical products increased from 9\% of the total exports in 1995 to $29 \%$ in 2016, while the imports of the industry also increased from $21 \%$ in 1991 to $27 \%$ in 2016 (UNCTAD). Thus, there is evidence that the increasing exports came with an increasing import-demand, such as inputs for the production process. Therefore, the FDI attracted by Romania in the sector could be possibly exportdriven (second category).

In the case of the food industry, FDI dropped, exports increased, and imports stayed relatively stable throughout the period examined, indicating that the declining FDI was probably of the first category.

Other sectors in which the FDI in the Romanian economy seem to be of the first category are the fuel industry and the cement-ceramics industry. In both cases, FDI increased while exports and imports decreased.

In the metal products industry, FDI and exports decreased but imports slightly increased. More specifically, the exports of metal products decreased from $15 \%$ of total Romanian exports in 1995 to $6 \%$ in 2016 while the imports of these products increased from 5\% in 1995 to $7 \%$ in 2016 of the total imports (UNCTAD). This could mean that these products were export-oriented and the FDI attracted was of the second category. Therefore, a downtrend in FDI led to a decrease of exports. Additionally, metal products could be significant inflows for other industries, such as mechanical products and vehicles, whose exports increased, and some of the FDI could be an intermediate category of FDI between the first and the second.

Therefore, Romanian FDI in the manufacturing industry between the years 2004 and 2016 is both market-seeking (first category) and export-oriented (second category). 


\subsection{The Case of Slovakia}

\subsubsection{Market-Seeking FDI: Tariffs, GDP, And National Currency}

As it can be seen from Fig. 4, Slovakia's FDI-w.t.percentage had an upward trend until 2008. After Slovakia's accession to the EU in 2004 and until 2008, FDI stock increased but at a decreasing pace. After 2008, 1 year before the country's accession to the EMU, Slovakia's FDI stock started to decrease. The relative position of the country as a receiver of FDI deteriorated since FDI stock in Slovakia diminished from $0.33 \%$ of the world total in 2008 to $0.16 \%$ in 2016 (UNCTAD).

In 1994, the application of high tariffs on imports (WTO 1995) was an incentive for attracting FDI of the first category in order to overcome the costs that resulted from the imposition of duties on the imported goods. The country started to phase out tariffs in 1995, a course necessary before the country's accession to the EU (Slovak Republic.org n.d.). This process was carried out by a number of agreements (EEFTA, EFTA, EEA). In 2004 Slovakia continued its course to a free market economy by accessing the EU, which did not negatively affect FDI attraction. Taking into account the high dependence on Slovakia's FDI coming from the EU members (OECD), a negative effect on attracting FDI of the first category would be expected. However, this fact did not influence the FDI attracted, which continued to increase.

Between 1993 and 2009, Slovakia's national currency depreciated in real terms (IMF), which was an incentive for attracting FDI of the first category in order to bypass exchange rate barriers and may explain, to some extent, the increased FDI.

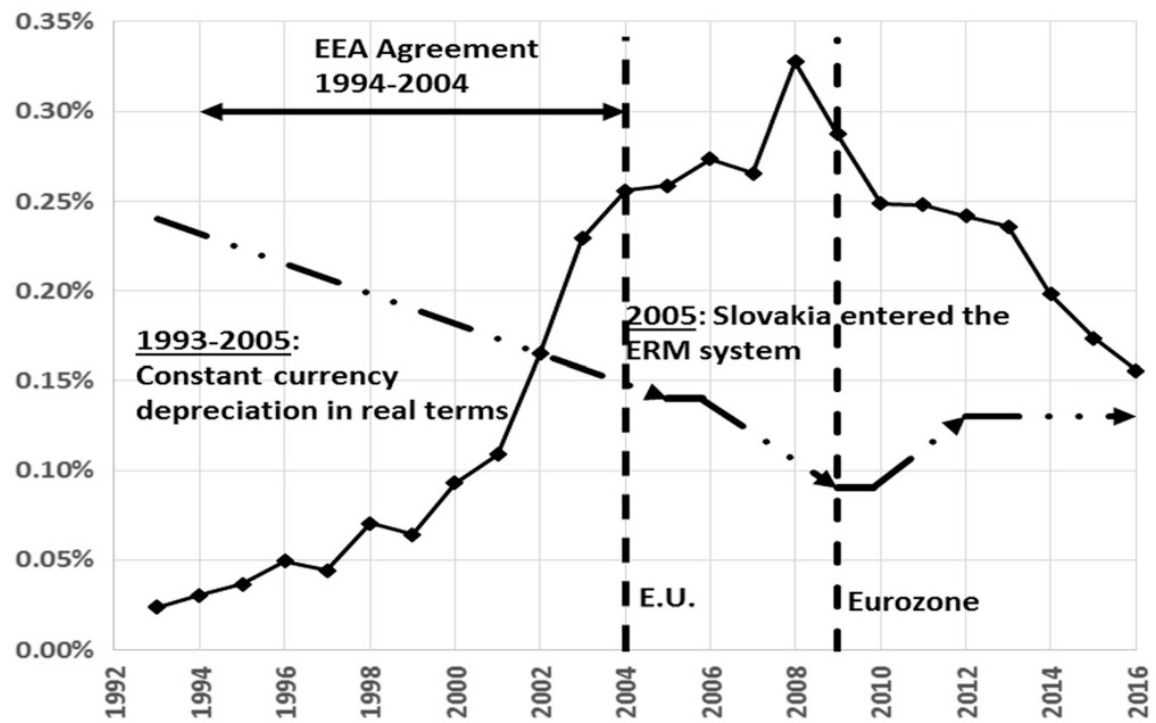

Fig. 4 FDI stock of Slovakia (\% of total world), 1993-2016. Source: UNCTAD \& IMF 
Therefore, although the incentive to circumvent tariff protectionism for attracting FDI had faded, the incentive to circumvent the exchange rate protection remained for foreign firms until 2009. After 2009, Slovakia accessed the EMU and there is no national currency under which FDI inflows can be explained, while FDI decreased considerably.

The geographical distance between the investor's country and the host country, as well as the transportation costs, don't seem to benefit the FDI of the first category since Slovakia's main investors (OECD) and trade partners (UNCTAD) are nearby countries of the EU.

Moreover, both GDP and FDI-w.t.percentage increased between the years 1994 and 2008 (AMECO). The two variables have a strong positive relationship ( $\rho=0.82$ ) between 1994 and 2016, which indicates that the growth of the Slovakian economy is positively related to market-seeking FDI. However, this is confirmed until 2009 since after that year the two variables seemed to disconnect.

\subsubsection{Export-Oriented FDI: Wage-Productivity Relationship and Geographic Proximity}

There was a decrease in Slovakia's ULC between the years 1997 and 2008 (AMECO), which could theoretically explain, to some extent, the increase of FDI. However, between the years 2008 and 2016, ULC increased. The weak negative correlation $(\rho=-0.52)$ between FDI-w.t.percentage and the ULC for the period 1995-2016 means that the cost competitiveness of Slovakia's economy has a weak relationship with the attraction of FDI.

An advantage of Slovakia, as a host country of FDI of the second category, is its geographical location. According to the three major car industries invested in the country, Slovakia was selected mostly because of its geographical location, great infrastructure, proximity to EU member states and growing economy in comparison with another member of V4 (Bratscht 2012, pp. 10-16).

\subsubsection{FDI and Trade Balance of Slovakia}

As can be seen from Fig. 5, Slovakian trade balance improves with some fluctuations after 1998. Slovakia's FDI-w.t.percentage has an upward trend until 2008 and the country's trade balance improves simultaneously. After 2008, Slovakia's trade balance continuous to improve while FDI-w.t.percentage starts to decrease. In particular, Slovakia has a trade surplus after 2009, while FDI falls significantly. FDI-w.t.percentage and X/M have a weak positive relationship $(\rho=0.56)$ between the years 1994 and 2016, which means that FDI is connected only to some extent to the external trade.

Moreover, Slovakia's trade balance continuous to improve after the country's accession to both the EU and the EMU. Nevertheless, after the country's accession to the EMU, X/M and FDI follow opposite directions. 


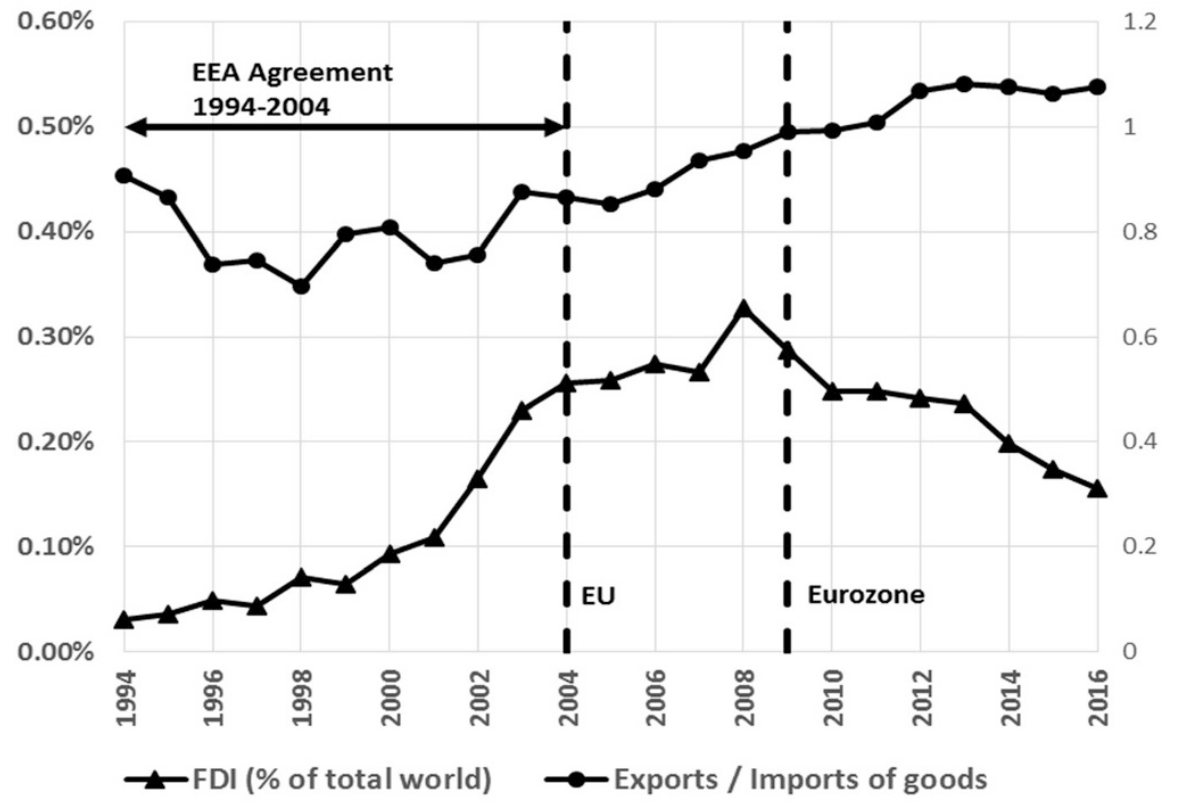

Fig. 5 FDI stock (\% total world) and exports/imports of goods of Slovakia (1994-2016). Source: UNCTAD \& AMECO

The relationship between exports and FDI-w.t.percentage has a positive correlation $(\rho=0.64)$ between 1994-2016, indicating the probable presence of FDI of the second category. The relationship between imports and FDI-w.t.percentage was strong and positive $(\rho=0.70)$ between the years 1994 and 2016. As in the case of Romania, the increase of Slovakian imports could be partly explained as a result of import-demands necessary for the production process created by increased FDI. In any case, Slovakia's FDI (like Romania's) doesn't seem to have significantly substituted imports.

Given the above, the trade surplus after 2009 cannot be attributed to the rising FDI of the first or second category, despite the evidence about the presence of FDI of the second category for the whole period examined. Between the years 1998 and 2003, FDI attracted by the service sector is higher than FDI attracted by the industrial sector absorbing about 55\% and 36\% of FDI, respectively. After 2004 and until 2007, FDI in the industrial sector accounted for almost $50 \%$ of the Slovakian FDI, more than the service sector, while during the same period Slovakia's trade balance was improving (OECD). The high increase of FDI-w.t.percentage between 2002 and 2004 is related with the establishment of the two car industries, Peugeot and KIA (Bratscht 2012, pp. 10-16). However, after 2009, FDI inflows in Slovakia are again mostly attracted by service sector, which absorbed approximately the $50 \%$ of Slovakia's FDI and in particular by non-tradable sectors or sectors that are not directly connected to external trade and have unknown impact to the trade balance. 
Thus, to the extent of any influence of FDI on trade balance, the improved trade balance, despite the decline of FDI after 2008, could only be due to the positive effect of earlier FDI, especially the one of the second category.

\subsubsection{Slovakia's FDI Positions by Industry \& Exports and Imports Structure}

As it can be seen from Fig. 6, the automotive industry is a leading sector of FDI attracted by Slovakia. In particular, three major car industries invested in the country: Volkswagen Slovakia, KIA Motors and PSA Peugeot Citroen (Bratscht 2012, pp. 10-16). Volkswagen Slovakia was founded in 1991, while the other two companies invested in Slovakia shortly before its accession to the EU. It should be noted that these two investments had a determining role in the rapid rise of the FDI of this sector, while FDI significantly increased from almost $0 \%$ in 2002 to $9 \%$ in 2006 and finally reached approximately $6 \%$ in 2016 . There is a major increase in exports of vehicles and transport equipment accounting $29 \%$ of the Slovakian exports in 2016 (UNCTAD) which were related to FDI that has taken place. It can be concluded that FDI attracted is mainly directed to the world market (second category).

In the food products sector there is a decrease in FDI from $8.8 \%$ in 1998 to $2 \%$ in 2016, while exports and imports remained relatively stable, constituting approximately $5 \%$ of the Slovakian imports and exports respectively (UNCTAD). This could mean that FDI of this sector has an unclear orientation (first or second category).

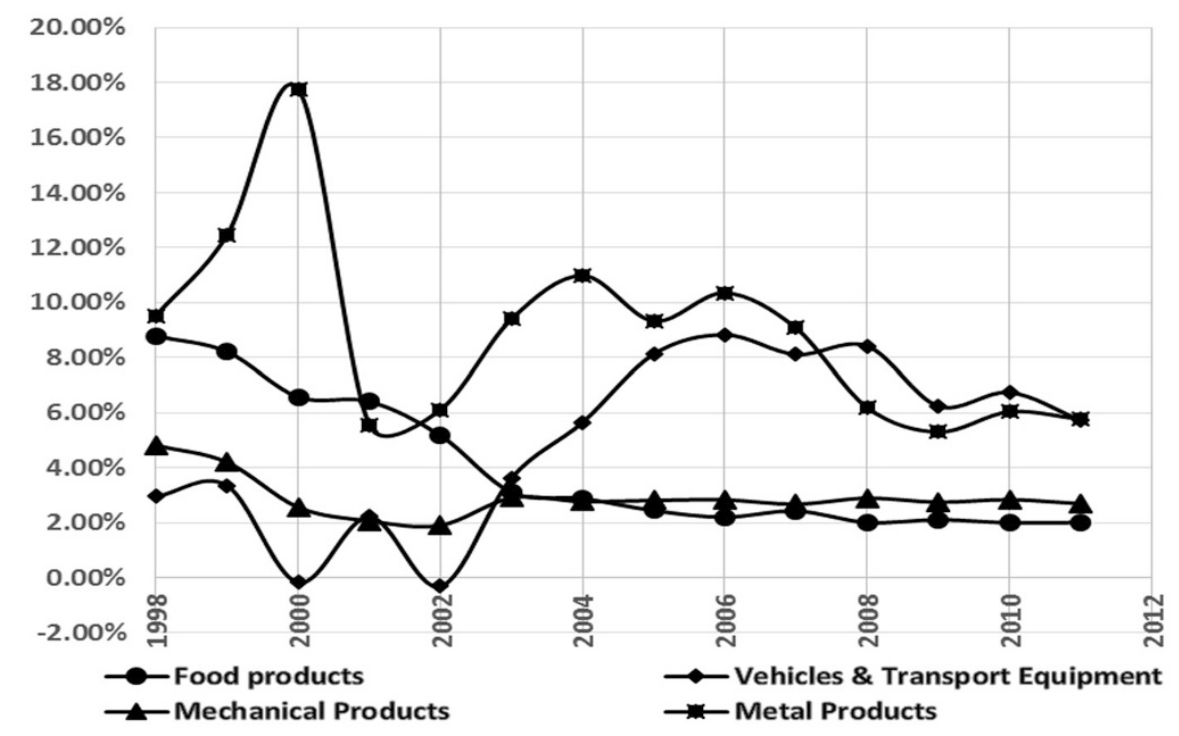

Fig. 6 FDI distribution by industry (1998-2011), (\% of total FDI positions of Slovakia). Source: OECD 
In mechanical products industry there was a major increase in both exports and imports for the whole period (UNCTAD) occupying almost the 33\% of Slovakian exports and imports respectively in 2016, while FDI remained stable at about $3 \%$ of the total Slovakian FDI. This probably means that FDI attracted is directed to both domestic and world market (first and second category). Moreover, a part of this sector may constitute inflows for other industries, such as Vehicles and Transport Equipment, whose exports also increase (first category).

Another major sector is the one of metal products. FDI had an upward trend until 2000 but diminished from $17.8 \%$ in 2000 to $5.8 \%$ in 2016 of the total FDI received, while exports and imports remained stable constituting approximately $10 \%$ of the Slovakian imports and exports respectively (UNCTAD). This could mean that part of this FDI is export-oriented (second category). Moreover, FDI of the sector of metal products could be significant inflows for other industries, such as mechanical products and vehicles, whose exports also increase (first category).

Slovakia's FDI, between the years 1998 and 2011, is mainly export-oriented (second category) while market-seeking FDI, apart from covering domestic needs, also consists important inflows for production for other industries.

\subsection{The Case of Greece}

\subsubsection{Market-Seeking FDI: Tariffs, GDP and National Currency}

As it can be seen from Fig. 7 Greece's FDI-w.t.percentage has an overall downfall trend while some fluctuations over some sub-periods can be noted. The FDI's downfall starts after 1984, i.e. 3 years after the country's accession to the European Economic Community (EEC). During the 1990's FDI continues to decline. The relative position of the country as a receiver of FDI deteriorated since FDI-w.t. percentage diminished from $0.84 \%$ of the world total in 1984 to $0.31 \%$ in 1995 , 2 years after Greek accession to the Single Market and even more to $0.18 \%$ in 2000 , finally reaching $0.10 \%$ of the world total in 2016 (UNCTAD). Therefore, it seems that the accession to the EU and the EMU has negatively affected FDI inflows. Moreover, FDI's course confirms the view that Greece is not an attractive country for FDI in the global economic environment.

After 1981, Greece had to accept the abolition of tariffs and capital control up to 1985, while the whole process was completed in 1993. Since Greece's main trading partners are EU countries (UNCTAD), the incentive of bypassing trade barriers for attracting market-seeking FDI does not seem to apply.

Moreover, the drachma's general appreciation in real terms during the 1990s (AMECO) ("pre-euro" era) could, to some extent, explain the non-attracting FDI. After 2001, the year that Greece accessed to the EMU, FDI stock remains on a low level and since Greece's main investors are EU countries FDI for exchange rate protection could not exist. 


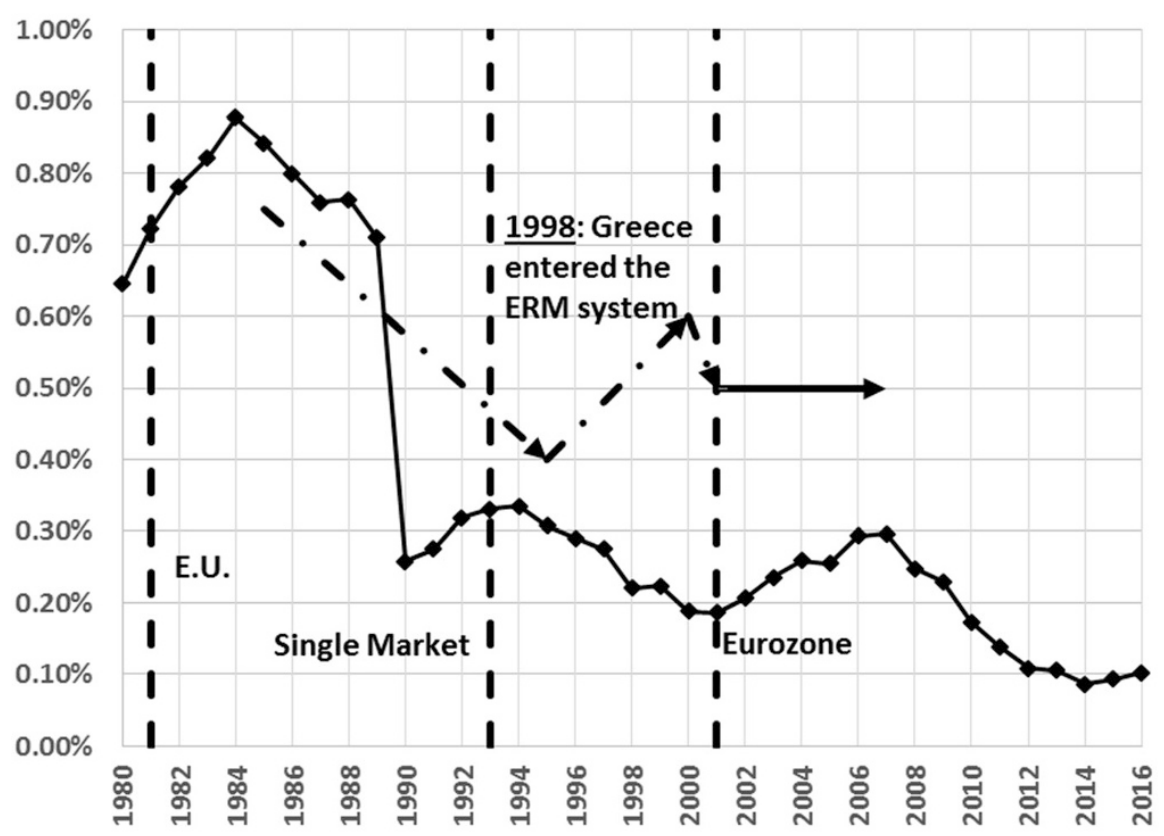

Fig. 7 FDI stock of Greece (\% of total world), 1980-2016. Source: UNCTAD \& IMF

Greece's geographical position like Romania's and Slovakia's, is not an incentive for attracting market-seeking FDI, taking into account that Greece's main investors (OECD) and trade partners are nearby countries of the EU (UNCTAD).

Greece's GDP and FDI-w.t.percentage have different directions until 2007 (AMECO). The correlation of the two variables is $\rho=0.12$ between the years 1994 and 2016, indicating that GDP changes are not an incentive for attracting market-seeking FDI. It must be noted that the continuous decline of GDP after 2008 is related to the global economic crisis and the austerity measures undertaken by the Greek government (Economakis et al. 2016).

\subsubsection{Export-Oriented FDI: Wage-Productivity Relationship and Geographic Proximity}

There is a sharp decrease in the Greece's ULC during the period 1983-1996 and for the years to follow, despite some fluctuations, it remains on low level. The correlation between FDI-w.t.percentage and ULC for the period 1981-2016 is strong and positive $(\rho=0.70)$, indicating that the improving cost competitiveness does not influence the level of FDI attracted by Greece.

Like Romania and Slovakia, the geographic proximity of Greece with the other EU countries, which are its main countries investors, could be an incentive for 
export-oriented FDI. However, this incentive is not activated in the case of Greece given the collapse of FDI.

\subsubsection{FDI and Trade Balance of Greece}

As it can be seen from Fig. 8, Greece's trade balance deteriorates, especially between the years 2002 and 2003, after the country's accession to the EMU. Greece's FDI-w. t.percentage had a downfall trend after 1984 with the only exception between the years 2002 and 2007 that had a small upward trend, which coincides for the years 2003-2005 with the trade balance amelioration. FDI-w.t.percentage and X/M have a strong negative relationship $(\rho=-0.74)$, for the period 1994-2016 which means that FDI is not connected to the external trade. After 2008, Greece's trade balance improves as a result of the economic crisis and the restrictive measures which led to decreasing imports (Economakis et al. 2016) and FDI and trade balance are completely disconnected.

The FDI-w.t.percentage and exports have a strong negative correlation ( $\rho=-0.74$ ) between the years 1994 and 1016 indicating that FDI does not connect with exports. The relationship between imports and FDI-w.t.percentage is insignificant $(\rho=-0.08)$ between the years 1994 and 1016 .

FDI in Greece is mostly attracted by non-tradable sectors or sectors that are not connected to the external trade. It is worth mentioning that in 2001 the service sector was absorbing the $60 \%$ and the industry sector the $35 \%$ of the total FDI received by

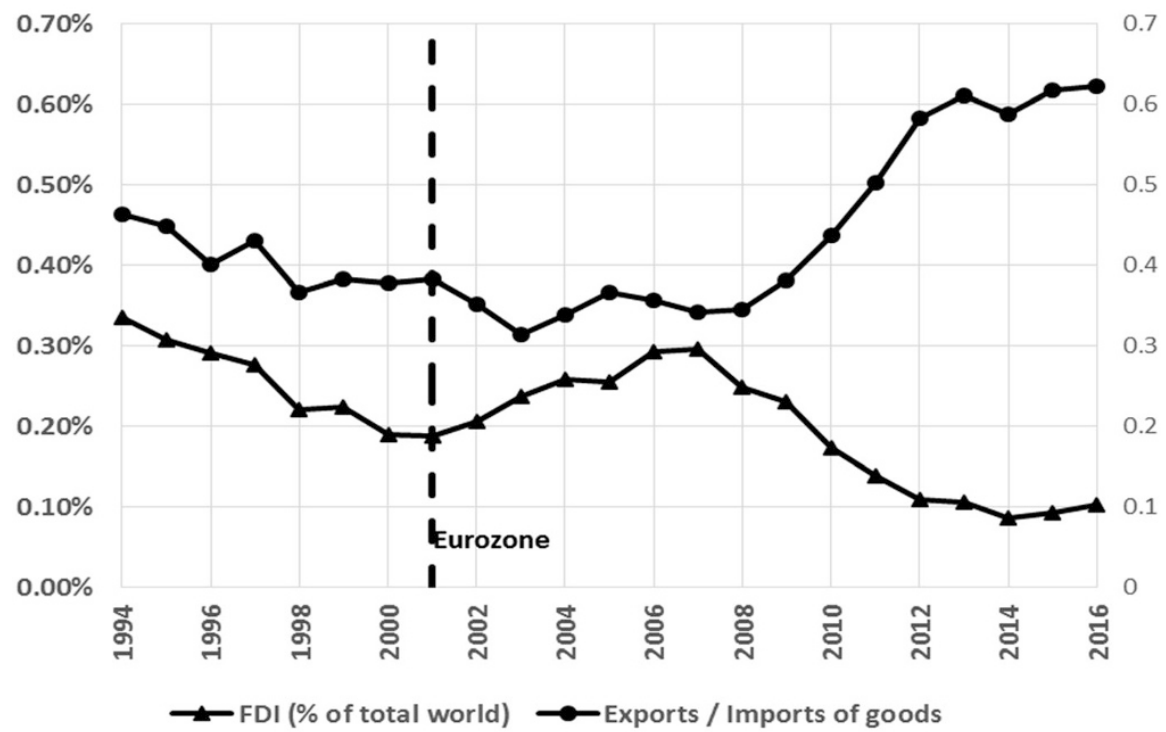

Fig. 8 FDI stock (\% total world) and exports/imports of goods of Greece (1994-2016). Source: UNCTAD \& AMECO 
Greece and in 2011 these percentages were almost the same (OECD), a fact that explains the trade balance deficit.

\subsubsection{Greece's FDI Positions by Industry \& Exports and Imports Structure}

As it can be seen from Fig. 9 FDI attracted by the Greece's manufacturing sector is lower than $40 \%$ of the total FDI received between the years 2001 and 2011 (OECD).

FDI attracted by the food products sector has a decrease from $19 \%$ in 2005 to $13.7 \%$ in 2016 (OECD). Moreover, the exports of the sector diminished from $30 \%$ in 1995 to $17.4 \%$ in 2014 , and finally reached $22.7 \%$ in 2016 , while imports seem to have remained relatively stable constituting $13 \%$ of the Greek imports during the years examined (UNCTAD). Therefore, FDI in this sector has an unclear orientation (first or/and second category).

As far as the pharmaceutical products are concerned, FDI also has an unclear orientation.

FDI of the fuel industry had fluctuations, absorbing 10.7\% in 2005 and $6.3 \%$ in 2016 of the total FDI attracted (UNCTAD). Moreover, fuel imports could, by their nature, consist of inputs for other industries. Greece's fuel imports and exports also increased by approximately 30\% between the years 1995 and 2013, which means that this industry's products are both export-oriented and for domestic use as well.

Given the above, FDI in Greece's manufacturing sector remained low during the period 2001-2011.

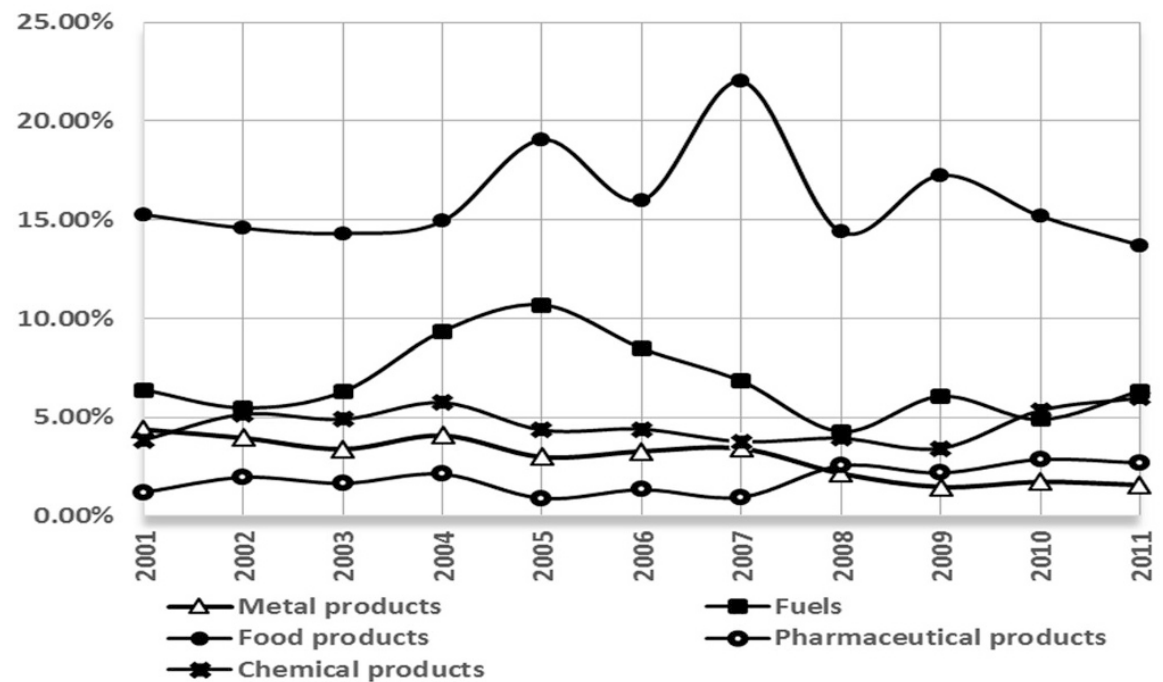

Fig. 9 FDI distribution by industry (2001-2011), (\% of total FDI positions of Greece). Source: OECD 


\section{Complexity}

Figure 10 presents the ECI of the three countries examined and also ECI of Germany as a benchmark, since "Germany is the second-most complex economy in the world after Japan and it is the second most diversified country after Italy" (Felipe and Kumar 2011, p. 10).

For Slovakia, ECI remains high throughout the period examined compared to the other two countries. Romania's ECI presents a clear upward trend during the recent years. Greece has a lower ECI compared to both Slovakia and Romania, and after 2010, i.e. during the ongoing Greek economic crisis, ECI turned negative.

From the definition of "economic complexity", Slovakia's export product mix is expected to be dominated by more "complex products", i.e. products of a higher technological level, while Greece's negative index indicates exports of low-tech products (OECD; Di Mauro et al. 2010).

Although primary and low technology products are Romania's main export products (UNCTAD), the downturn of exports of low technology products and the significant increase of exports of medium technology products since the mid-1990s (UNCTAD) can explain the upward trend of ECI during the recent years. Romania's FDI has followed the same trend. In particular, vehicles and transport equipment, which is a leading sector attracting Romanian FDI in recent years, is classified as sector of medium-high technological level, which indicates that ECI could be related, to some extent, to Romanian FDI.

Medium-tech products have dominated Slovakian exports since the mid-1990s while primary and low-tech export products have declined (UNCTAD), which

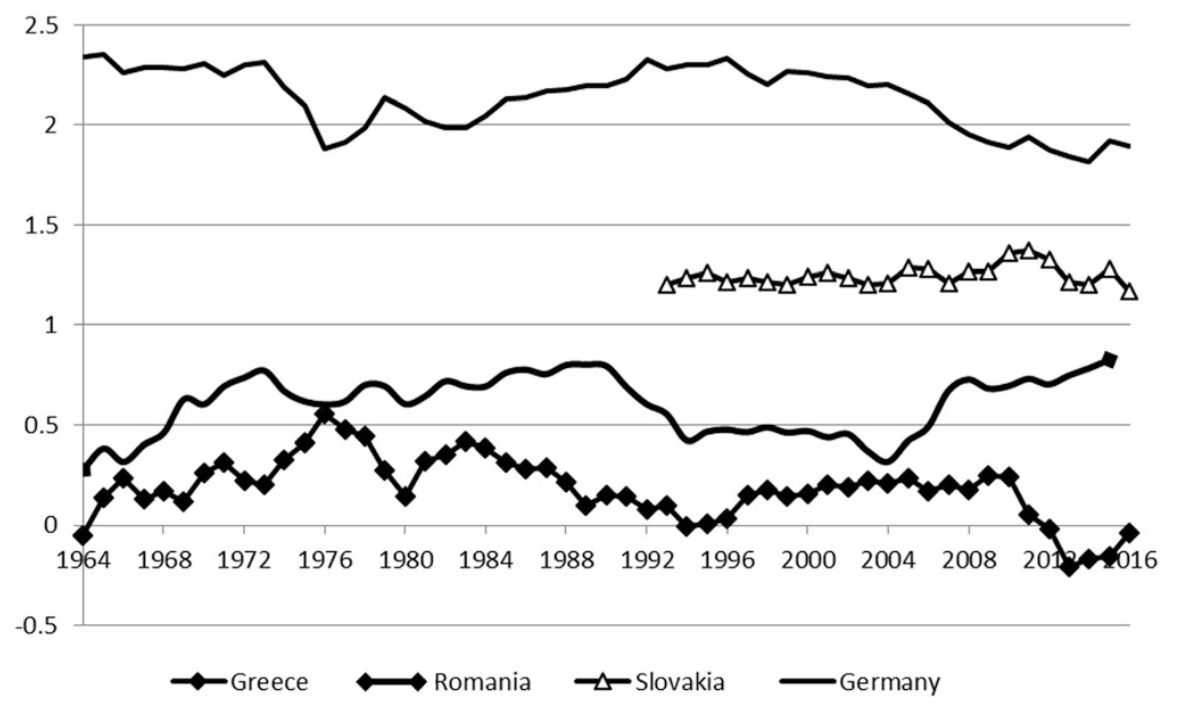

Fig. 10 Economic Complexity Intex (ECI) of Germany, Greece, Romania, Slovakia (1964-2016). Source: Atlas of Economic Complexity 
explains Slovakia's higher ECI. Given that the technological level of exports is positively related to the income elasticity of demand for exports and the latter is positively related to the amelioration of the trade of balance (Thirlwall 1991), Slovakian trade balance amelioration since 1998 is connected to the improving technological level of its exports. Moreover, there has been a significant increase of FDI in the sector of vehicles and transport equipment (medium-high technology level) but a decrease in the sectors of food products and metal products (low technology and low-medium technology, respectively). Consequently, Slovakia's relatively high economic complexity attracts specific FDI categories, especially the ones with a relatively higher level of economic complexity.

Finally, in the case of Greece, after the mid-1990s, the overwhelming dominance of primary product exports (UNCTAD) is linked to the low ECI of the country. The dominance of FDI in low-tech food products indicates that the country is classified as a simpler economy and therefore the economic complexity is not an incentive for attracting FDI.

\section{Conclusions}

Summarizing, the process of European integration does not seem to have had the same effect on the FDI attracted by Romania, Slovakia and Greece; however, it seems to be connected with a general downgrading of all countries as receivers of FDI. In the case of Romania and Greece, this deterioration is connected to the accession of the countries to the EU while in the case of Slovakia to the accession of the country to the EMU.

The effect of FDI on the trade balance for all countries examined in the context of European integration is rather vague. Throughout the period examined, FDI is either weakly connected (Slovakia) or disconnected (Romania and Greece) to the external trade. This indicates the limited impact of FDI of the first and second category on the total FDI in these countries despite the evidence of presence of FDI of the second category for Romania and Slovakia. It is worth noting that for Romania and Slovakia, FDI and trade balance followed opposite directions after the accession to the EU and the EMU, respectively. Greece's trade balance deteriorated or ameliorated independently of FDI after the country's accession to the EEC/EU.

For both Romania and Slovakia, although the incentive to circumvent tariff protectionism for attracting FDI has faded, the incentive to circumvent the exchange rate protection remains for foreign firms. In the case of Greece, the phasing out of tariffs and the exchange rate have had an effect on FDI attractiveness.

The size of the market has a positive relationship with FDI in the case of Romania and Slovakia but has no relationship with FDI in the case of Greece. Moreover, the low ULC seemed to attract FDI in the case of Romania and Slovakia but played no role in the case of Greece.

Greece's, Romania's, and Slovakia's geographical positions is not an incentive for attracting market-seeking FDI, taking into account that their main investors and 
trade partners are nearby countries of the EU. However, the geographic proximity of the three countries could be an incentive for export-oriented FDI.

Finally, economic complexity seems to explain, to some extent, the relative attractiveness of FDI of the three countries examined, and especially of FDI directed to more advanced technological sectors.

\section{References}

Andrei, D. M. (2014). Foreign direct investment (FDI) in Romania. Empirical evidence using restricted and unrestricted ECM models. Internal Auditing \& Risk Management, 2(34), 1-12.

Bratscht, Z. P. (2012). Effects of Slovakia's entry to EU (including adoption of euro) on Slovakia's car industry (pp. 1-21). Ypsilanti, MI: Eastern Michigan University.

Busch, K. (1992). Europe after 1992: Economic, ecological and social prospects of the single internal market. Athens: Kritiki [in Greek].

Di Mauro, F., Forster, K., \& Lima, A. (2010). The global downturn and its impact on euro area exports and competitiveness. Occasional Paper Series, ECB, 119.

Dobreanu, C. (2014). The German model. Forbes Magazine, 125(13 June), 86.

Economakis, G., Anastassopoulos, G., Koteas, A., \& Leonidas, M. (2005, October 13-15). Foreign direct investments: An inquiry into the Bulgarian case. Paper presented at the International Conference Managing Global Trends and Challenges in a Turbulent Economy, organized by the Department of Business Administration, University of Aegean, Chios.

Economakis, G., Frunzaru, V., \& Zisimopoulos, I. (2016). The economic crisis and industrial relations: Greece and Romania in comparison. East-West: Journal of Economics and Business, $X I X(1), 51-77$.

Fan, X., \& Dickie, P. M. (2000). The contribution of foreign direct investment to growth and stability: A post-crisis ASEAN-5 review. ASEAN Economic Bulletin, 17(3), 312-323.

Felipe, J., \& Kumar, U. (2011). Unit labor costs in the Eurozone: The competitiveness debate again (Working Paper 651). Levy Economics Institute of Bard College.

Giannitsis, S. (1983). The Greek industry: Growth and crisis. Athens: Gutenberg [in Greek].

Gibson, H. D. (2010). Development of the Greek economy by sector (1995-2003). In G. Economou, I. Sampathai, \& G. Simigiannis (Eds.), Current account of Greece: Causes of imbalances and policy proposals (pp. 335-364). Athens: Report of Bank of Greece [in Greek].

Hausmann, R., Hidalgo, C. A., Bustos, S., Coscia, M., Simoes, A., \& Yildirim, M. A. (2011). The Atlas of economic complexity. In Center for international development at Harvard University. Cambridge, MA: Puritan Press.

Iammarino, S., \& Pitelis, C. (1999, August). Foreign direct investment and less favoured regions: Greek FDI in Bulgaria and Romania. Paper presented at the ERSA Conference Paper.

International Monetary Fund (IMF). Accessed September 10, 2017, from http://data.imf.org/site moved.html

Lankes, H. P., \& Venables, A. J. (1996). Foreign direct investment in economic transition: The changing pattern of investments. The Economics of Transition, 4(2), 331-347.

Lim, E.-G. (2001). Determinants of, and the relation between, foreign direct investment and growth: A summary of the recent literature (IMF Working Paper). Accessed September 10, 2017, from http://www.imf.org/external/pubs/ft/wp/2001/wp01175.pdf

Marinescu, N., \& Szeles, M. R. (2010). Real convergence in the CEECs, euro area accession and the role of Romania. The European Journal of Comparative Economics, 7(1), 181-202.

Milios, J., \& Ioakeimoglou, I. (1990). The internationalization of Greek capitalism and the balance of payments. Athens: Exsantas [in Greek]. 
National Bank of Romania (NBR). (2004-2016). Foreign investment in Romania. Annual Reports. Accessed September 11, 2017, from http://www.bnr.ro/PublicationDocuments.aspx? icid $=14364$

Thirlwall, A. P. (1991). Krugman's 45-degree rule. Journal of Post Keynesian Economics, 14(1), 23-28.

Tsantilas, F. (2009). Greek investments in the Balkans (Diploma Thesis). University of Macedonia, Economic and Social Sciences, MSc. in Business Administration, Thessaloniki [in Greek]. Accessed September 10, 2017, from http://dspace.lib.uom.gr/bitstream/2159/13499/1/ TsantilasMsc2009.pdf

World Trade Organization (WTO). (1995, November). Slovakia. Accessed September 10, 2017, from https://www.wto.org/english/tratop_e/tpr_e/tp019_e.htm

\section{Online Sources}

AMECO. Accessed September 10, 2017, from http://ec.europa.eu/economy_finance/ameco/user/ serie/SelectSerie.cfm

Atlas of Economic Complexity - Center for International Development at Harvard University. Accessed September 10, 2017, from http://atlas.cid.harvard.edu/

OECD. Stat. Accessed September 10, 2017, from http://stats.oecd.org/

Slovak Republic.org. (n.d). European Union. Accessed September 13, 2017, from http://www. slovak-republic.org/eu/

UNCTAD. Accessed September 10, 2017, from http://www.unctad.org

Open Access This chapter is licensed under the terms of the Creative Commons Attribution 4.0 International License (http://creativecommons.org/licenses/by/4.0/), which permits use, sharing, adaptation, distribution and reproduction in any medium or format, as long as you give appropriate credit to the original author(s) and the source, provide a link to the Creative Commons licence and indicate if changes were made.

The images or other third party material in this chapter are included in the chapter's Creative Commons licence, unless indicated otherwise in a credit line to the material. If material is not included in the chapter's Creative Commons licence and your intended use is not permitted by statutory regulation or exceeds the permitted use, you will need to obtain permission directly from the copyright holder. 